\title{
Modulations in Gene Expression and Mapping of Genes Associated with Cyst Nematode Infection of Soybean
}

\author{
Zarir Vaghchhipawala, ${ }^{1}$ Ronald Bassüner, ${ }^{1}$ Kathryn Clayton, ${ }^{1}$ Kimberley Lewers, ${ }^{1}$ Randy Shoemaker, ${ }^{3}$ \\ and Sally Mackenzie ${ }^{1}$ \\ ${ }^{1}$ Department of Agronomy, Purdue University, West Lafayette, IN 47907, U.S.A.; ${ }^{2}$ Department of Agronomy, \\ lowa State University, Ames 50011, U.S.A.; ${ }^{3}$ USDA-ARS and Department of Agronomy, lowa State \\ University, Ames 50011, U.S.A. \\ Accepted 3 October 2000.
}

Infection of the soybean root by the soybean cyst nematode (SCN) (Heterodera glycines Ichinohe) induces a welldocumented, yet poorly understood, response by the host plant. The plant response, involving the differentiation of a feeding structure, or "syncytium," facilitates the feeding and reproduction of the nematode to the detriment of the host. We used a genetic system involving a single dominant soybean gene conferring susceptibility to an inbred nematode strain, VL1, to characterize the nematode-host interaction in susceptible line PI 89008. The restriction fragment length polymorphism marker $\mathrm{pB053}$, shown to map to a major SCN resistance locus, cosegregates with resistance among $F_{2}$ progeny from the PI $89008 \times$ PI 88287 cross. Cytological examination of the infection process confirmed that syncytium development in this genetic system is similar to that reported by others who used noninbred nematode lines. Our study of infected root tissue in the susceptible line PI 89008 revealed a number of genes enhanced in expression. Among these are catalase, cyclin,

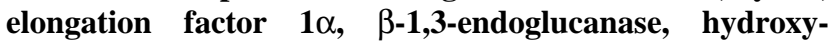
methylglutaryl coenzyme A reductase, heat shock protein 70, late embryonic abundant protein 14, and formylglycinamidine ribonucleotide synthase, all of which we have genetically positioned on the public linkage map of soybean. Formylglycinamidine ribonucleotide synthase was found to be tightly linked with a major quantitative trait locus for SCN resistance. Our observations are consistent with the hypothesis proposed by others that feeding site development involves the dramatic modulation of gene expression relative to surrounding root cells.

Corresponding author: S. Mackenzie; Current address: N305 Beadle Center for Genetics Research, University of Nebraska, Lincoln 685880665, U.S.A.; Telephone: +1-402-472-6997; Fax +1-402-472-3139; E-mail smackenzie2@unl.edu

Current address of R. Bassüner: Pharmacia Co., Monsanto Campus, IPT Business Unit, 8520 University Green, Middleton, WI 53562, U.S.A.

Current address of K. Clayton: Dow Agrosciences LLC, Indianapolis, IN 46268-1054, U.S.A.

Novel sequence information appears under the GenBank/EMBL/DDBJ accession nos. U95397, U97653, AF000378, AF000379, AF061564, AF000377, AF294324, AF294325, AF294394 and AF061565.
Additional keywords: cytology, gene mapping, Glycine max, plant-nematode interactions.

Soybean cyst nematode (SCN) (Heterodera glycines Ichinohe) infection of soybean roots presents not only an important agronomic problem to soybean growers of the midwestern and southern United States, but a fascinating phenomenon with regard to plant root cell response. The cyst nematode infection of susceptible soybean lines is accompanied by a series of cellular changes within the plant at the site of feeding initiation that leads to a structure known as a "syncytium." Some of the defining characteristics of syncytium development include enlarged nucleoli, increased density of endoplasmic reticulum, increased number of mitochondria, changes in vacuolization, and cell wall dissolution of surrounding cells (Endo 1991). The complexity of this process suggests that the expression of several plant genes is involved in this developmental change. In fact, plant genes encoding extensin-like proteins and late embryonic abundant (LEA) protein (Van der Eycken et al. 1996), catalase (Niebel et al. 1995), cyclin (Niebel et al. 1996), membrane channel protein (Opperman et al. 1994; Wilson et al. 1994; Yamamoto et al. 1990), the E2 enzyme of the ubiquitination pathway, Myb proteins, and RNA polymerase II (Bird and Wilson 1994) have been identified to be nematode-responsive in various plant systems. Recent investigations by Hermsmeier et al. (1998) with differential displays to characterize the early compatible interaction between soybean and SCN revealed a collection of cDNAs that showed homologies to the large subunit of transcription factor TFIIA from Arabidopsis thali$a n a$, the soybean auxin down-regulated gene ADR12, aldolase A, and the small GTP-binding soybean protein sral, among others.

Resistance to SCN has been reported in several genotypes of soybean, and quantitative genetic analysis has allowed the development of various genetic models, generally involving multiple resistance loci acting in concert (Concibido et al. 1996b; Rao Arelli et al. 1992; Vierling et al. 1996; Webb et al. 1995). At the cytological level, early stages of the infection process in a resistant (zero to three cysts per root) line may appear quite similar to the compatible interaction (Acedo et al. 
1984; Kim and Riggs 1992; Mahalingam and Skorupska 1996). Typically, these formations do not support the full life cycle of the female nematode and degenerate a few days after initiation.

The development of inbred nematode strains and their recurrent selection for zero-cyst phenotype on a resistant plant genotype has proven an effective strategy for the genetic dissection of resistance. This strategy was used in the development of an inbred nematode strain, first reported as $\mathrm{Hg} 1$ (Luedders 1987) and recently redesignated VL1 (Bird and Riddle 1994) with soybean resistant line PI 88287 and susceptible line PI 89008. Within this genetic system, resistance is conferred by a single recessive resistance gene (Luedders 1987). We have adopted this system to characterize the soybean-SCN interaction with emphasis on the susceptibility response by identifying a group of SCN-responsive loci in soybean. Positioning these loci on the public soybean map should allow us to identify associations, if any, to known soybean-SCN-resistance quantitative trait loci (QTL).

\section{RESULTS}

Cytological changes in roots associated

with the susceptible soybean response

to infection by nematode inbred strain VL1.

To confirm that observations made with susceptible host PI 89008 infected with inbred VL1 would be representative of a normal cyst nematode infection process, we conducted a cytological study during infection. Figure 1 illustrates a normal development of a feeding site. In a compatible interaction between susceptible line PI 89008 and inbred VL1, the process involved the proliferation of primary syncytium initials, radiating out with wall dissolution of adjacent cells, the formation of a highly vacuolar cytoplasm (Fig. 1B to D), and the development of cell wall in-growths typical of transfer cells
(Gunning and Steer 1996) alongside xylem elements (Fig. 1D). Upon completion of the nematode life cycle, the cytoplasm of the syncytium-component cells deteriorates (Fig. 1E and F), eventually leaving near-empty cells with cell wall stubs and in-growths (Fig. 1G). In contrast, nematode penetration of the root of the resistant line PI 88287 occasionally resulted only in the formation of initial syncytium structures that degenerated before completion of a nematode life cycle, as indicated by the detachment of the cytoplasm from the cell wall (data not shown). The cytological observations resembled earlier descriptions of the resistant reaction in different genetic systems (Acedo et al. 1984; Kim and Riggs 1992; Mahalingam and Skorupska 1996).

\section{Modulation of root gene expression in susceptible host PI 89008 in response to infection by nematode inbred strain VL1.}

The dramatic cytological changes induced in the soybean root upon infection by the cyst nematode imply that several plant genes are recruited by the nematode to act in concert in order to facilitate syncytium development. Empirical selection (from literature), cDNA subtraction, and differential display produced a collection of plant genes that were further examined for response to VL1 infection in the susceptible host PI 89008. Several gene candidates were selected on the basis of previous reports (Cramer et al. 1993; Laxalt et al. 1996; Niebel et al. 1995; Niebel et al. 1996; Van der Eycken et al. 1996; Wang et al. 1995; Yoshikawa et al. 1990). Gene expression was assayed by reverse transcription of mRNA followed by polymerase chain reaction (RT-PCR). The responsive genes examined here are listed by their identity and origin in Tables 1 and 2. Selected clones that were enhanced in expression but whose identity could not be determined do not appear in the tables.

Table 1. Clones identified by differential display and cDNA subtractive hybridization

\begin{tabular}{|c|c|c|c|c|c|}
\hline cDNA Identity & $\begin{array}{l}\text { Clone } \\
\text { designation }^{\text {a }}\end{array}$ & $\begin{array}{l}\text { Database } \\
\text { accession no. }\end{array}$ & $\begin{array}{c}\text { Oligonucleotide primers for reverse transcription } \\
\text { polymerase chain reaction (RT-PCR) }\end{array}$ & $\begin{array}{l}\text { RT-PCR } \\
\text { results }^{c}\end{array}$ & Mapped \\
\hline $\begin{array}{l}\text { Elongation factor } \\
\qquad \mathrm{EF}-1 \alpha\end{array}$ & pSMK2D & U95397 & $\begin{array}{l}5^{\prime}>\text { GCTGGTATCTCCAAGGATGG <3' } \\
5^{\prime}>\text { GGCTTGAGGACACCAGTCTCGATACG }<3^{\prime}\end{array}$ & $+($ weak $)$ & \\
\hline $\begin{array}{l}\beta \text {-glucosidase } \\
\text { EC 3.2.1.21 }\end{array}$ & pSMK7D & AF000378 & $\begin{array}{l}5^{\prime}>\text { GGGACCTGTGATTCTTGTCATAATG }<3^{\prime} \\
5^{\prime}>\text { GGATTATAAGACCCAAAAATAAC }<3^{\prime}\end{array}$ & + & \\
\hline $\begin{array}{l}\text { Heat shock protein } \\
\text { HSP70 }\end{array}$ & pSMK8S & AF000379 & $\begin{array}{l}5^{\prime}>\text { GTGCAAATCTAGAGGCACCTC }<3^{\prime} \\
5^{\prime}>\text { GAAGAAATCTTCTCTGCTGTCAAG }<3,\end{array}$ & - & \\
\hline Nematode 28S rRNA & pSMK251S & AF294324 & $\begin{array}{l}5^{\prime}>\text { GAATGTGGGTCAGYCGATCCTAAGG }<3^{\prime} \\
5^{\prime}>\text { AGACACCACAGGAACCGYGG }<3,\end{array}$ & Control & \\
\hline $\begin{array}{l}30 \mathrm{~S} \text { ribosomal pro- } \\
\text { tein S5 }\end{array}$ & pSMK11D & AF294394 & $\begin{array}{l}5^{\prime}>\text { GGCATTAAAAATGTGCTATCCAAGTCG }<3^{\prime} \\
5^{\prime}>\text { CGCTTGATGAGGCTACGCACC }<3^{\prime}\end{array}$ & & \\
\hline $\begin{array}{l}\text { Small ribo- } \\
\text { nucleoprotein } \mathrm{E}\end{array}$ & pSMK230-188S & AF294325 & $\begin{array}{l}5^{\prime}>\text { CGCATTCAGATTTGGCTATTTG }<3^{\prime} \\
5^{\prime}>\text { CATTAAAGTTATGTTATCTCC }<3^{\prime}\end{array}$ & & \\
\hline Soybean 18S rRNA & pSMK12D & AF061565 & $\begin{array}{l}5^{\prime}>\text { CCTTGCTTSTTGCTTTACTAAAT }<3^{\prime} \\
5^{\prime}>\text { ATGCACCTTTTCGTTTGTTTCGGAG }<3,\end{array}$ & Control & \\
\hline$\beta$-tubulin & pSMK1S & $\mathrm{U} 21296$ & $\begin{array}{l}5^{\prime}>\text { CGTACAGAACAAGAACTCCTCC }<3^{\prime} \\
5^{\prime}>\text { CATGCAGCCATGGCTTCGTC }<3^{\prime}\end{array}$ & $+($ weak $)$ & \\
\hline FGAM synthase & PSMK3D & AF000377 & $\begin{array}{l}5^{\prime}>\text { GCTATTGATGGAGGGAAAGACAG }<3^{\prime} \\
5^{\prime}>\text { GCCATCTCTAAGGCACAAACTAG }<3^{\prime}\end{array}$ & +++ & Yes \\
\hline
\end{tabular}


To prepare the mRNA used to construct the cDNA subtraction library and carry out the differential display procedures, it was necessary to identify the most densely populated root tissues with feeding sites and to estimate the timing of syncytium development. Inoculations were made with prepared eggs rather than stage $\mathrm{J} 2$ nematode juveniles; as a result, infections were not well synchronized. The infection results, presented in Table 3, show that from day 10 the resistant and susceptible root responses are readily distinguishable. Because we were most interested in the changes of the soybean root gene expression pattern defining the accommodation of sedentary females in the root (approximately day 10 after infection) (Table 3), root material taken from PI 89008 at days 3 to 21 after infection were pooled for total RNA-mRNA isolation. For control mRNA preparation, noninfected PI 89008 root material of the same developmental stages was collected and pooled. Data in Table 3 provide only a timeline for infection phenotype under inoculation conditions used in our study and not considered a formal analysis of the infection process.
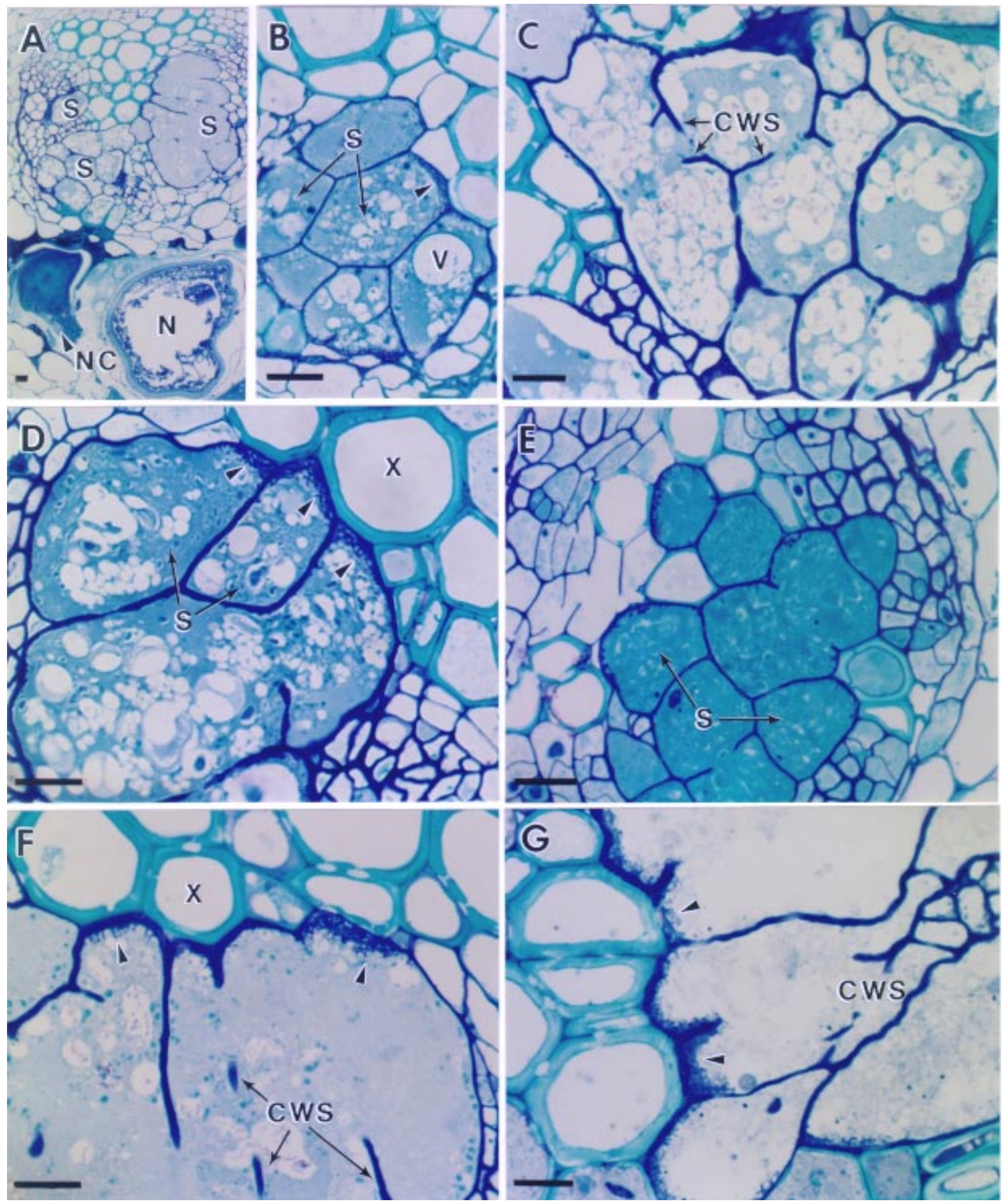

44 / Molecular Plant-Microbe Interactions 
To test for enhanced expression by RT-PCR, careful dissection of the regions encompassing the feeding sites was carried out, producing extremely small tissue samples (approximately $5 \mathrm{mg}$ per collection). Subsequent preparation of poly $(\mathrm{A})^{+}$ RNA resulted in a very low mRNA yield. Thus, a semiquantitative assay for template concentration was developed with RT-PCR on the basis of known concentrations of leaf mRNA (Fig. 2A). RT-PCR assays were carried out with mRNA templates from infected and uninfected root of the susceptible line PI 89008 and leaf tissues. Results of the RTPCR assay, with regard to enhanced amplification upon infection, are summarized in Tables 1 and 2, with sample RT-PCR results demonstrated in Figure 2B, results of which were independently replicated in subsequent RT-PCR assays with spectrophotometrically quantified RNA templates (data not shown). Clones that were regarded as enhanced in their expression had to show comparable differential expression with the use of both templates.

RT-PCR results show that several genes were enhanced in their expression in the VL1-induced syncytia within the roots. Many of these clones were unidentifiable on the basis of sequence analysis and database searches (data not shown), whereas other clones selected for RT-PCR could be identified on the basis of DNA sequence homologies (Tables 1 and 2). The expression of all selected genes was readily detected in leaves (except for clones of nematode origin), although some were expressed at comparable levels in infected root tissue but at undetectable levels (with our assay) in the uninfected control. Increased template concentration in the uninfected control allowed visualization of the RT-PCR products, indicating that gene expression was enhanced by nematode infection.

With the design of the primers matching divergent DNA regions, the assay discriminated between individual genes from within families such as HSP70, endoglucanase, and cyclin. Only particular genes from each class demonstrated enhanced expression in infected root (Fig. 2B).

The cytology of syncytium development and enhanced expression of several genes suggested a strong influence of the nematode on cellular processes during infection. Therefore, it was appropriate to further investigate the genetics of plantnematode interaction in this system. First, we examined the genetics of soybean susceptibility to nematode inbred strain VL1, providing a tentative location of a gene conferring sus- ceptibility on the public soybean map. We then determined the map locations of several of the soybean genes responsive to nematode infection.

\section{Genetics and mapping of susceptibility in PI 88287 to nematode inbred VL1.}

Genetic characterization of the inbred nematode strain VL1 was limited to examining its ability to establish a compatible interaction on several host differentials commonly used for the assignment of infection pathotype (Golden et al. 1970). Table 4 shows the results of infection with VL1 inbred strain on host differentials, allowing us to deduce that VL1 behaves as a pathotype or "race" 5 .

We used VL1 to confirm Luedders' results (1987) regarding the presence of a single gene in PI 88287 that confers recessive resistance to cyst nematode. In the VL1 screening procedure, susceptible and resistant classes were distinct, as evidenced in Tables 3 and 5, with resistance classified as a zero to three cyst phenotype. An $\mathrm{F}_{1}$ progeny from a PI $89008 \times$ PI 88287 cross produced a wider range of cysts per plant than did the parents under controlled growth conditions (Table 5). Despite this variation, the $F_{1}$ population was susceptible to VL1.

The number of cysts per plant varied among the susceptible class in the $F_{2}$ population, although the data best fit a $1: 3$ model (resistant-susceptible) of a single dominant gene for cyst nematode susceptibility (Table 5) and the additive gene action was not evident (data not shown). A PI $89008 \times$ PI 88287 cross population of $55 \mathrm{~F}_{2}$ plants was used to map the susceptibility locus on the basis of linkage associations with known markers on the public soybean map. The population segregated 40:15 (susceptible-resistant) $\left(\chi_{3: 1}^{2}=0.148\right)$. Restriction endonuclease digestion of genomic DNAs with BamH1 enzyme allowed the detection of a dominant (45:10, $\chi_{3: 1}^{2}=1.36$ ) DNA polymorphism (data not shown) with marker B_053 from linkage group $\mathrm{G}$ as probe (Shoemaker et al. 1996). The polymorphic fragment demonstrated linkage $\left(\chi_{9: 3: 3: 1}^{2}=28.3, P<0.01\right)$ with the susceptible phenotype in segregating $\mathrm{F}_{2}$ progeny. Of the 55 plants tested, five appeared recombinant for the marker. It was not feasible to further resolve the map position of the susceptibility locus in this mapping population because of lack of DNA polymorphisms for other markers in the vicinity (Bng122, C006V; 10 enzymes tested). Linkage of the SCN resistance gene to this map loca-

\section{$\longleftarrow$}

Fig. 1. Light microscopic examination of syncytium development in susceptible (PI 89008) soybean roots infected with nematode inbred line VL1 (Heterodera glycines Ichinohe). A to G, Response to soybean cyst nematode observed approximately 4 to 30 days after infection. All specimens were embedded in Quetol resin (Electron Microscopy Sciences, Fort Washington, PA, U.S.A.), except E, which was embedded in LR White resin (Electron Microscopy Sciences) and prepared from an infected root section grown in vitro on a medium, according to Lauritis et al. (1983). Scale bars $=10 \mu \mathrm{m}$; CWS = cell wall stubs; $\mathrm{N}=$ nematode $; \mathrm{NC}=$ necrotic matter; $\mathrm{S}=$ syncytium-component cell; $\mathrm{V}=$ vacuole $; \mathrm{X}=$ xylem element. A, Root cross section (PI 89008) at low magnification showing three syncytium-component cells at different stages of development as a result of staggered reinfection inside the central vascular cylinder of the root and adjacent to the xylem elements. Syncytium cells distorted the morphology of the vascular cylinder. The nematode is situated next to the endodermis surrounding the central vascular cylinder. The cavity in which the nematode resides is filled with necrotic material that stains dark. B, Young syncytium showing seven cells with different degrees of vacuolization. Cell wall breakdown has started to develop. Irregular depositions of cell wall material are visible, predominantly in the areas of the syncytium cell walls adjacent to xylem elements (arrowhead); approximately 4 days after infection. C, Higher magnification of one syncytium shown in A. Vacuolization has progressed, and significant cell wall breakdown generates cell wall stubs and establishes a cytoplasmic continuum between syncytium-component cells; approximately 8 days after infection. D, In the mature syncytium, the vacuoles tend to be smaller and become irregular in form. Extensive fingerlike in-growths are evident (arrowheads) at cell walls adjacent to xylem cells; approximately 14 days after infection. E, In an aging syncytium, the vacuoles have disappeared and irregular membranous material resides in the cytoplasm. Syncytium has reached its maximum extension; approximately 19 days after infection. F, High magnification of an older degenerated syncytium with cell wall in-growths (arrowheads) shown in A. Cell wall stubs mark the position of once intact cell walls; approximately 24 days after infection. G, Decayed syncytium is void of cytoplasm. Cell wall in-growths (arrowheads) and perforated cell walls and cell wall stubs remain of the nematode feeding site; approximately 30 days after infection. 
tion was further confirmed by the identification of a randomly amplified polymorphic DNA marker (RAPD) linked to the susceptibility locus with bulked segregant analysis (Michelmore et al. 1991). This marker (SCN_rad) also mapped to the region encompassing marker B_053 (Fig. 3). Linkage detected with marker B_053 and SCN_rad allowed us to tentatively assign the map position of the susceptibility locus to linkage group G (Fig. 4). This is the vicinity in which a major cyst nematode resistance QTL was identified in two other studies by multiple sources of resistance (Concibido et al. 1996b; Webb et al. 1995). On the basis of these data, it is not possible to distinguish whether the resistance locus in PI 88287 is allelic to any of the loci reported previously.

\section{Map locations of eight SCN-responsive loci in soybean.}

Several QTLs have been identified in association with resistance to cyst nematode in soybean (Chang et al. 1997;
Concibido et al. 1994; Concibido et al. 1996a; Concibido et al. 1996b; Concibido et al. 1997; Vierling et al. 1996; Webb et al. 1995). Therefore, it was appropriate to determine whether any of the genes we identified to be responsive to nematode infection reside within a map location associated with nematode infection. In this study, eight of the SCN-responsive loci were placed on the public soybean map (Shoemaker et al. 1996).

Restriction enzymes used to detect polymorphisms in the $\mathrm{F}_{2}$ and recombinant inbred (RIL) population were AccI, BamHI, DraI, EcoRI, EcoRV, HaeIII, HhaI, HindIII, SspI, and TaqI. In the $\mathrm{F}_{2}$ population derived from A81-356022 and PI 468.916 (Shoemaker et al. 1996), cDNAs were mapped to 10 linkage groups (Fig. 4). In the RIL population derived from BSR 101 and PI 437.654 (Baltazar and Mansur 1992), cDNAs mapped to five linkage groups (Fig. 4). Members of the gene family elongation factor $1 \alpha(\mathrm{EF}-1 \alpha)$ and $\mathrm{HMG} \mathrm{CoA}$ reductase mapped to three and five linkage groups (A1, L, Q, and C1,

Table 2. Previously reported soybean genes examined for enhanced expression upon nematode infection

\begin{tabular}{|c|c|c|c|c|c|}
\hline cDNA Identity & $\begin{array}{l}\text { Clone } \\
\text { designation }\end{array}$ & $\begin{array}{l}\text { Database } \\
\text { accession no. }\end{array}$ & $\begin{array}{c}\text { Oligonucleotide primers for reverse transcription } \\
\text { polymerase chain reaction (RT-PCR) }\end{array}$ & $\begin{array}{l}\text { RT-PCR } \\
\text { results }^{b}\end{array}$ & Mapped \\
\hline Catalase, EC 1.11.1.6 & & Z12021 & $\begin{array}{l}5^{\prime}>\text { TGTGCCCATCACAACAATCAC }<3^{\prime} \\
5^{\prime}>\text { GATACTTGGCTTCAAGTTCAGG }<3^{\prime}\end{array}$ & +++ & Yes \\
\hline Cyclin & & D50868 & $\begin{array}{l}5^{\prime}>\text { GAACATTTGGGCAGCTATATTGG }<3^{\prime} \\
5^{\prime}>\text { GGTCTTCAAAGTAACAACTCGG }<3^{\prime}\end{array}$ & ++ & Yes \\
\hline Cyclin & & X62820 & $\begin{array}{l}5^{\prime}>\text { GGACTTTGACTGTGCCAACACC }<3^{\prime} \\
5^{\prime}>\text { GAAGCAGAACCTTCAGGCAGAAG }<3^{\prime}\end{array}$ & - & \\
\hline Elongation factor EF- $1 \alpha$ & & X56856 & $\begin{array}{l}5^{\prime}>\text { CAAACTCAAAGGATGACCCTGC }<3^{\prime} \\
5^{\prime}>\text { CTTCTGGGCAGCCTTGGTGACC }<3^{\prime}\end{array}$ & + & Yes \\
\hline $\begin{array}{l}\beta \text {-1,3-endoglucanase EC } \\
\text { 3.2.1.39 }\end{array}$ & & U41323 & $\begin{array}{l}5^{\prime}>\text { GATGGTGTCATCAGACATCTAGTG }<3^{\prime} \\
5^{\prime}>\text { CTTCTCATACTCTGGCTGCTTGTG }<3^{\prime}\end{array}$ & - & \\
\hline $\begin{array}{l}\beta \text {-1,3-endoglucanase EC } \\
\text { 3.2.1.39 }\end{array}$ & & U08405 & $\begin{array}{l}5^{\prime}>\text { CCACTTCTTGCCAACGTGTACCC }<3^{\prime} \\
5^{\prime}>\text { GACGCTCAGTATCAGCACCTGC }<3^{\prime}\end{array}$ & + & Yes \\
\hline $\begin{array}{l}\beta \text {-1,4-endoglucanase EC } \\
\text { 3.2.1.39 }\end{array}$ & & U34755 & $\begin{array}{l}5^{\prime}>\text { GCTAGTCACATTAATGGACTAGCC }<3^{\prime} \\
5^{\prime}>\text { GAGGTAACCAAGCTGGTTCACCG }<3^{\prime}\end{array}$ & - & \\
\hline 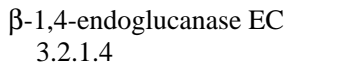 & & U00730 & $\begin{array}{l}5^{\prime}>\text { CCAAGGTGGGTTGCAATGAT }<3^{\prime} \\
5^{\prime}>\text { GCATCGATATGGGGAAACTGCAGAG }<3^{\prime}\end{array}$ & - & \\
\hline $\begin{array}{l}\beta \text {-1,4-endoglucanase EC } \\
\text { 3.2.1.4 }\end{array}$ & & U00731 & $\begin{array}{l}5^{\prime}>\text { CAGTTCATTGCATGCAAAGAA }<3^{\prime} \\
5^{\prime}>\text { ACTAAAGTTGGGATTAGCAGC }<3^{\prime}\end{array}$ & - & \\
\hline Heat shock protein HSP70 & & X62799 & $\begin{array}{l}5^{\prime}>\text { CCACAGCGCAGACAACTATTG }<3^{\prime} \\
5^{\prime}>\text { CATGAACCTGACTCTTGTCTATC }<3^{\prime}\end{array}$ & ++ & Yes \\
\hline $\begin{array}{l}\text { Hydroxymethylglutaryl CoA } \\
\text { reductase, EC 1.1.1.88 }\end{array}$ & pSMK81/82Y10 & U97653 & $\begin{array}{l}5^{\prime}>\text { GAGGGACGTGGGAAATCAGTTG }<3^{\prime} \\
5^{\prime}>\text { GTAAATTCAAGCAAGCAGATTGGG }<3^{\prime}\end{array}$ & ++ & Yes \\
\hline $\begin{array}{l}\text { Late embryonic abundant } \\
\text { protein type } 14 \text { (LEA14) }\end{array}$ & & U08108 & $\begin{array}{l}5^{\prime}>\text { CTATGTTGCGGAGAAAGTCACG }<3^{\prime} \\
5^{\prime}>\text { GGCAAACATGTCAGAGAGGGTTGG }<3^{\prime}\end{array}$ & +++ & Yes \\
\hline
\end{tabular}

${ }^{a}$ From GenBank, EMBL, and DDBJ databases.

$\mathrm{b}+++=$ highly enhanced, $++=$ moderately enhanced, and $+=$ slightly enhanced gene expression on nematode infection of the susceptible host. $-=$ no enhanced expression.

Table 3. Development of the VL1 nematode inbred on resistant (PI 88287) and susceptible (PI 89008) soybean lines ${ }^{\mathrm{a}}$

\begin{tabular}{|c|c|c|c|c|c|c|c|c|}
\hline \multirow{3}{*}{$\begin{array}{l}\text { Time } \\
(\text { DAI })^{\mathbf{b}}\end{array}$} & \multicolumn{4}{|c|}{ PI 88287} & \multicolumn{4}{|c|}{ PI 89008} \\
\hline & \multirow{2}{*}{$\begin{array}{c}\text { No. soybean cyst } \\
\text { nematode/cm of root }\end{array}$} & \multicolumn{2}{|c|}{ Late L4 and adult ${ }^{c}$} & \multirow{2}{*}{$\begin{array}{l}\text { No. cysts } \\
\text { per plant }^{d}\end{array}$} & \multirow{2}{*}{$\begin{array}{c}\text { No. soybean cyst } \\
\text { nematode/cm of root }\end{array}$} & \multicolumn{2}{|c|}{ Late L4 and adult ${ }^{c}$} & \multirow{2}{*}{$\begin{array}{l}\text { No. cysts } \\
\text { per plant }^{\mathrm{d}}\end{array}$} \\
\hline & & Male (\%) & Female (\%) & & & Male (\%) & $\operatorname{Female}(\%)$ & \\
\hline$\overline{1}$ & 0.0 & $*$ & $*$ & & 0.1 & $*$ & $*$ & \\
\hline 2 & 2.0 & $*$ & $*$ & & 2.4 & $*$ & $*$ & \\
\hline 4 & 4.6 & $*$ & $*$ & & 3.8 & $*$ & $*$ & \\
\hline 6 & 5.0 & $*$ & $*$ & & 5.5 & $*$ & $*$ & \\
\hline 10 & 11.5 & 2.7 & 0.0 & & 6.7 & 3.4 & 7.7 & \\
\hline 14 & 2.8 & 27.3 & 0.0 & & 4.3 & 7.8 & 46.2 & \\
\hline 19 & 3.3 & 64.0 & 0.0 & & 2.1 & 14.6 & 63.1 & \\
\hline 21 & 3.5 & 75.0 & 0.0 & & 1.8 & 15.7 & 76.3 & \\
\hline 38 & N/A & N/A & N/A & 0.0 & N/A & N/A & N/A & 74 \\
\hline
\end{tabular}


$\mathrm{D} 1, \mathrm{I}, \mathrm{K}, \mathrm{P})$, respectively, in the $\mathrm{F}_{2}$ population. No polymorphisms were detected with these cDNAs in the RIL population. Two of the cDNAs, glucanase (U08405) and catalase, were mapped only in the RIL population (linkage groups $\mathrm{J}$ and B2, respectively). Three of the cDNAs, LEA14, cyclin, and heat-shock protein (HSP70), were mapped in both populations (linkage groups G, C2, and D1, respectively). Formylglycinamidine ribonucleotide (FGAM) synthase was mapped to linkage group $\mathrm{G}$ in both populations. EF- $1 \alpha$ elongation factor was polymorphic in the RIL population with the restriction enzyme EcoRV but did not link to any known linkage group.

Four cDNAs mapped within the vicinity of previously reported SCN QTL markers. EF-1 $\alpha$ elongation factor was positioned 5.8 centimorgans (cM) from SCN QTL marker A_023 on linkage group $\mathrm{L}$ (Concibido et al. 1996a) in the $\mathrm{F}_{2}$ population. LEA14 was $30.0 \mathrm{cM}$ from SCN QTL marker A_378 on linkage group $G$ (Concibido et al. 1997) in the $F_{2}$ and RIL populations. Glucanase (U08405) was $39.6 \mathrm{cM}$ from SCN QTL marker locus B_032 on linkage group J (Concibido et al. 1994; Concibido et al. 1996a; Concibido et al. 1997) in the
RIL population. FGAM synthase was mapped to a $<3.0 \mathrm{cM}$ interval, flanked by markers Bng_122E and B_053T at the top of linkage group $\mathrm{G}$ (Fig. 3). Interestingly, the major soybean $\mathrm{SCN}$ resistance QTL ( $r h g l$ locus) also maps to the same interval on linkage group G (Mudge et al. 1997).

Four of the cDNAs mapped in regions known to contain resistance-gene analogs (RGAs) (Kanazin et al. 1996). EF-1 $\alpha$ cosegregated with RGA7 on linkage group $\mathrm{L}$ in the $\mathrm{F}_{2}$ population. One locus of HMG CoA reductase on linkage group $\mathrm{P}$ in the $\mathrm{F}_{2}$ population was located $5.7 \mathrm{cM}$ from RGA8. Glucanase (U08405) was $6.7 \mathrm{cM}$ from RGA3 on linkage group $\mathrm{J}$ in the RIL population, and HSP70 was $10.7 \mathrm{cM}$ from RGA1f on linkage group D1 in the $\mathrm{F}_{2}$ population (data not shown).

\section{DISCUSSION}

Complicating factors that have slowed progress in studies of soybean-nematode interactions are the genetic heterogeneity of SCN field populations, the environmental sensitivity of the infection process, and the difficulties inherent in locating
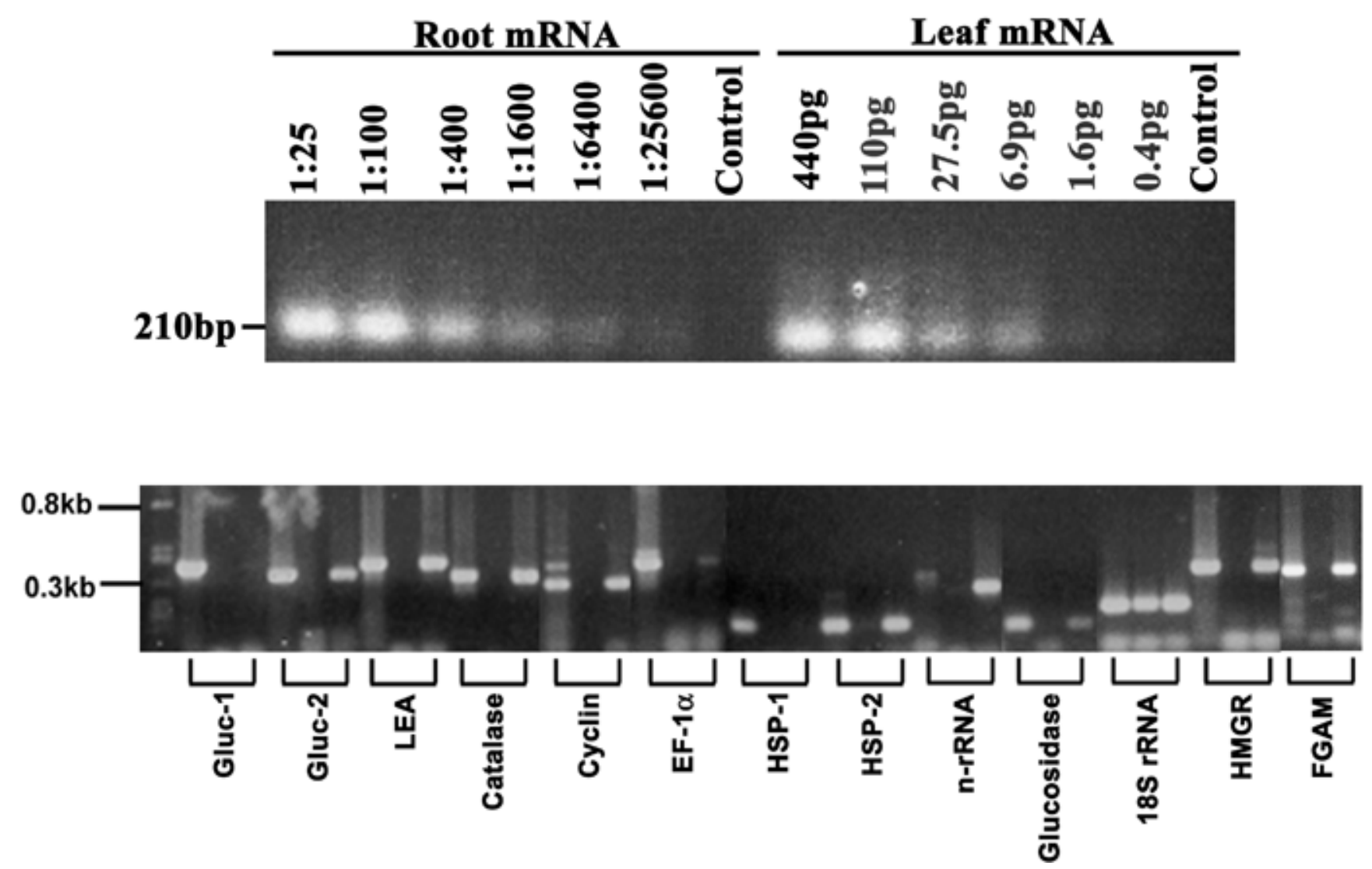

Fig. 2. Reverse transcript polymerase chain reaction (RT-PCR) analysis of soybean gene induction during infection of susceptible line PI 89008 by nematode inbred strain VL1. Upper gel, Titration of root mRNA against known quantities of leaf mRNA by RT-PCR with primers specific for soybean $18 \mathrm{~S}$ rRNA. On the right, the leaf mRNA was quantified spectrophotometrically and indicated amounts were subjected to RT-PCR with soybean $18 \mathrm{~S}$ rRNA-specific primers. This titration series was compared with a series of 1:25 to 1:25,600 dilutions of a root mRNA preparation. There was no mRNA in the control. Size of the amplification product (in base pairs) is indicated on the left. Lower gel, 1.2\% agarose gels after electrophoresis of PCR amplification products obtained by RT of mRNA from leaf, noninfected root, and infected root tissues (three lanes each) with specific primers, corresponding to the genes indicated at the bottom. Gluc- $1=\beta-1,3$-endoglucanase; gluc- $2=\beta-1,3$-endoglucanase; LEA $=$ late embryonic abundant protein type 14 ; EF$1 \mathrm{a}=$ elongation factor $1 \alpha$; HSP-1 = heat shock protein HSP70; HSP-2 = heat shock protein HSP70; n-rRNA = nematode $28 \mathrm{~S}$ ribosomal RNA; glucosidase $=\beta$-glucosidase; $18 \mathrm{~S}$ rRNA $=18 \mathrm{~S}$ ribosomal RNA; HMGR = hydroxymethylglutaryl CoA reductase and formylglycinamidine ribonucleotide synthase. Primers for soybean $18 \mathrm{~S}$ ribosomal RNA were used as internal standards to equalize the amount of mRNA from the three sources used in the assays. Nematode $28 \mathrm{~S}$ rRNA primers served as a negative control, giving a strong signal only in the mRNA sample from roots infected by nematodes. Molecular weights (in base pairs) are provided to the left. 
actively developing infection sites internal to the root and invisible at the surface. This investigation was directed toward implementing a genetically simplified system to facilitate more in-depth investigation of the soybean-nematode interac-

\section{MS LG G}

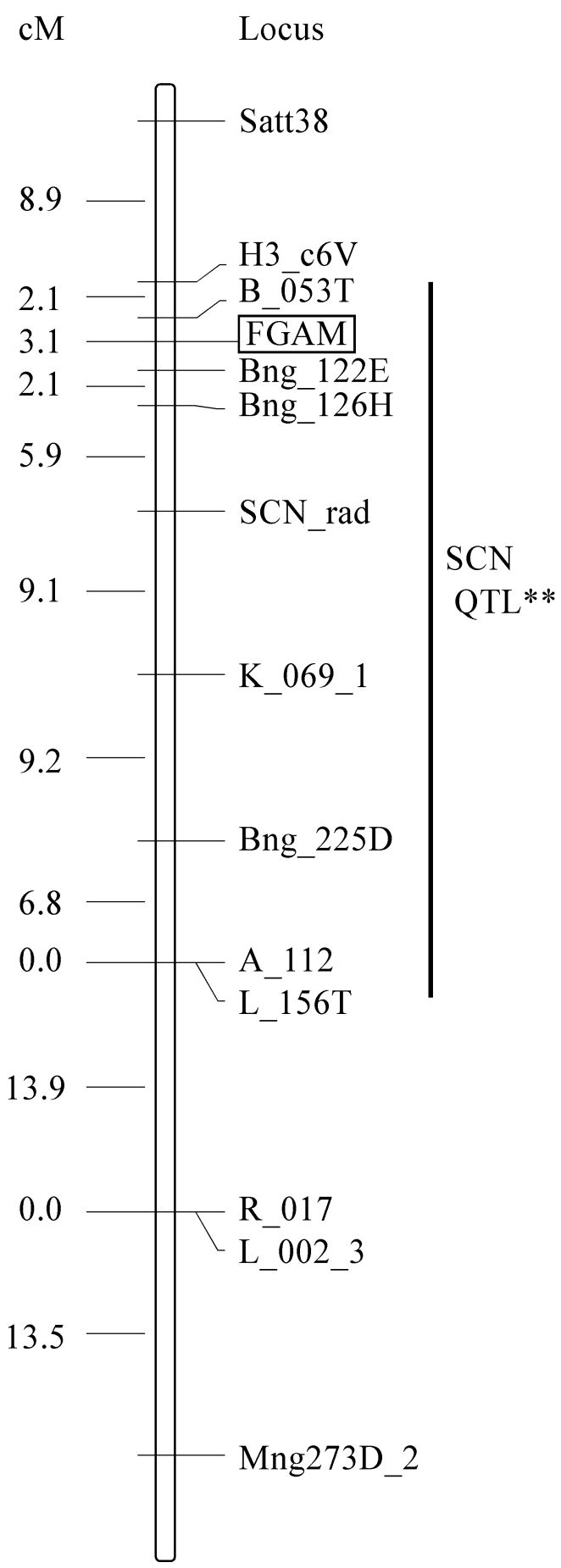

Fig. 3. Detailed map of a portion of linkage group G showing the approximate mapping location of formylglycinamidine ribonucleotide (FGAM). The 3.0 centimorgan interval delimited by markers B_053T and Bng_122E is shown in association to the FGAM locus. The mapping data set was used to position FGAM and SCN_rad to linkage group G, as in Cregan et al. (1999). tion. This system utilizes a homogeneous inbred cyst nematode population together with a highly resistant plant genotype. The PI 88287 displays an unambiguous resistant phenotype. With this system, we have initiated studies into the cellular and expressional changes that accompany the infection process.

Light microscopic examinations of the susceptible and resistant plant reactions show cellular responses similar to other described soybean-nematode systems (Endo 1991; Endo 1992; Kim and Riggs 1992). In our study, we extended the examination of the feeding site development to more than one life cycle of the nematode. The appearance of cell wall ingrowths in syncytium-component cells of the susceptible reaction resemble the appearance of transfer cells that have exhibited an enhanced capacity for uptake and passage of solutes described in other plant tissues (Gunning and Steer 1996). We could not detect such cell wall in-growths in the resistant reaction. Absence of cell wall in-growths may limit solutes to the syncytium in the resistant line, thus leading to premature termination of syncytium development.

Gene expression studies presented here and by other groups provide evidence that several host genes are recruited in the process of establishing a compatible interaction between the nematode and the plant. Some of these are homologous to genes with known functions, including plant genes encoding structural, housekeeping, and cell-cycle proteins. It was proposed that hydroxymethylglutaryl coenzyme A reductase (HMGR) enhanced upon nematode infection as a result of nematode dependence on the plant host for sterol biosynthesis (Cramer et al. 1993). Some enzymes might be involved in a general response to pathogens, including endo-1,3-glucanase (Yoshikawa et al. 1990) and cytosolic glyceraldehyde-3phosphate dehydrogenase (Laxalt et al. 1996). Results of our study suggest that several plant genes responsive to the nematode encode products important to normal cellular functions. It does not appear likely, from our investigations, that many genes are induced specifically or exclusively during feeding site initiation. Likewise, this is the case of plant genes induced by Meloidogyne incognita during giant cell formation (Bird 1996). In this regard, it is reasonable to suggest that the initiation of syncytia may be directed by a dramatic change in expression levels of several genes within the syncytium that are already expressed in surrounding tissues or, as has been hypothesized, that may be important to xylem development (Bird 1996).

We used RT-PCR to confirm nematode response of genes derived from cDNA subtraction and differential display. We also confirmed the approximate map location of the dominant susceptibility gene present in soybean line PI 89008 and determined the location of several of the nematode-responsive genes.

Mapping of QTLs associated with resistance to SCN has been conducted by several laboratories (Chang et al. 1997; Concibido et al. 1994; Concibido et al. 1996a; Concibido et al. 1996b; Vierling et al. 1996; Webb et al. 1995). Most report a genomic region where a molecular marker was significantly associated with resistance, which does not allow a precise positioning of the QTL on the genomic map. The use of PCR-based and publicly available markers by Concibido et al. (1996b) and the mapping of SCN resistance as a qualitative trait, however, paved the way for the definition 
of a major SCN resistance gene between markers B_053T and Bng_122D on linkage group G (Mudge et al. 1997). Here we tentatively assigned the locus effective in PI 88287 to this same region.
We identified a few linkages between the identified nematode-responsive genes and regions containing QTLs for resistance to SCN. Some of the mapped candidate genes were linked to resistance gene analogs, several of which have been
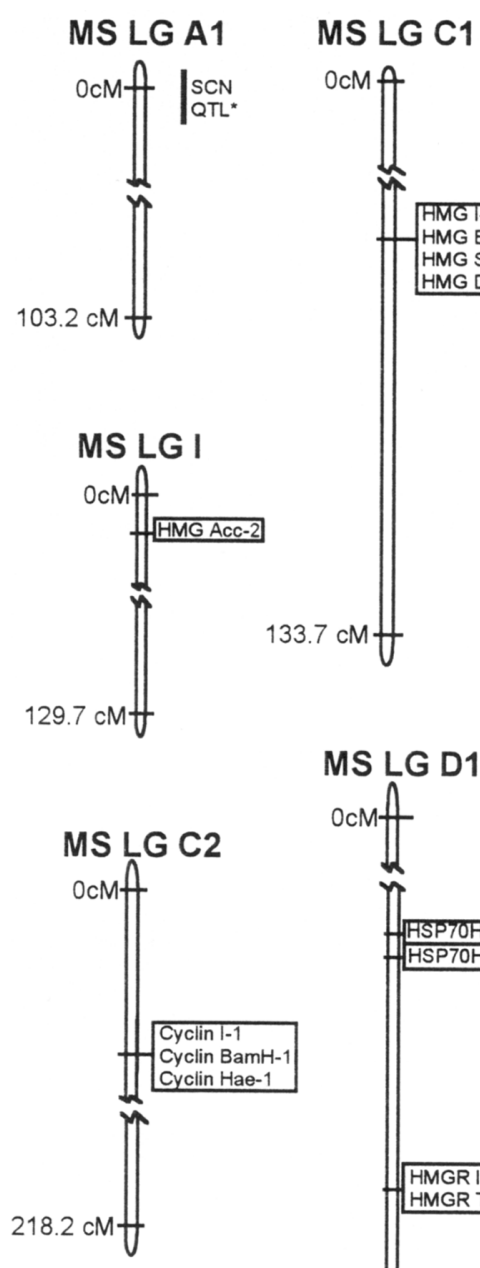<smiles>[C+]1CC12CC2</smiles>

MS LG C1
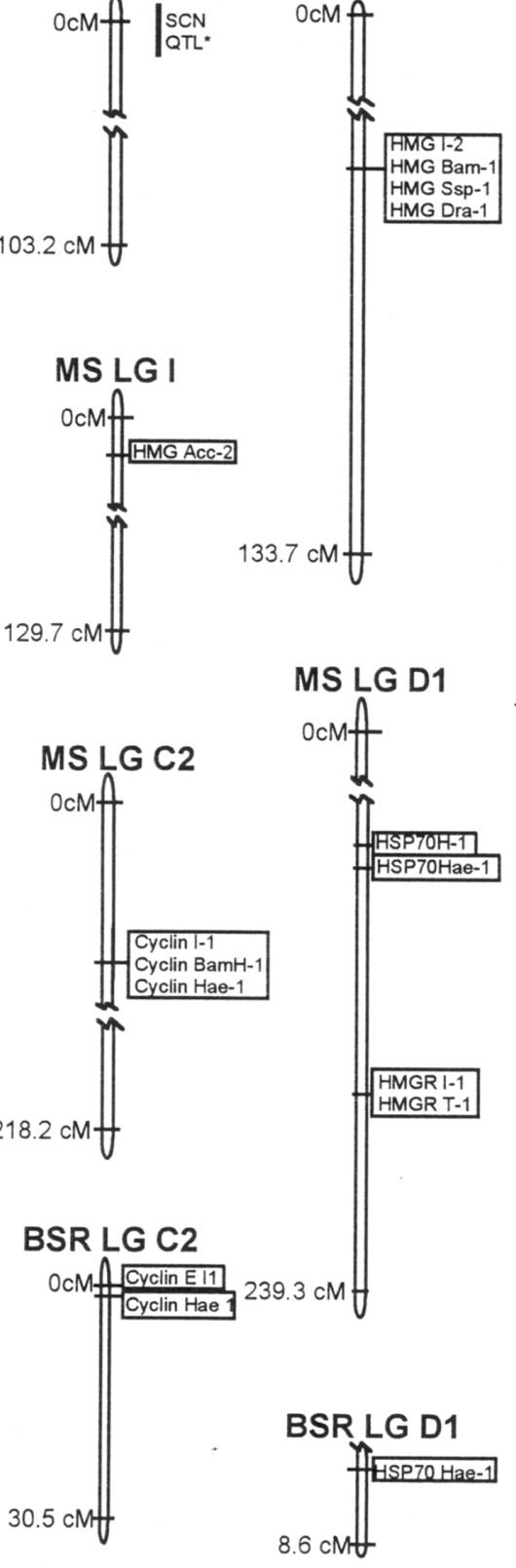

$152.6 \mathrm{cM}$
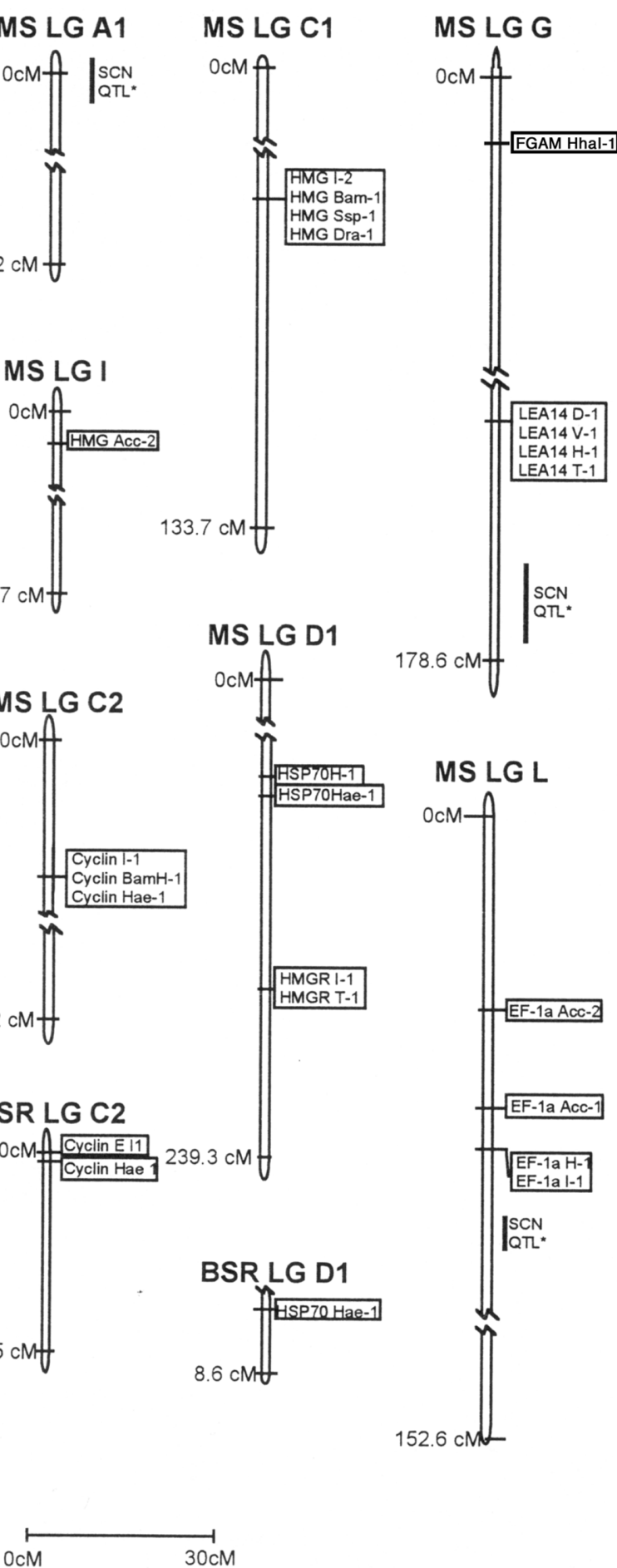
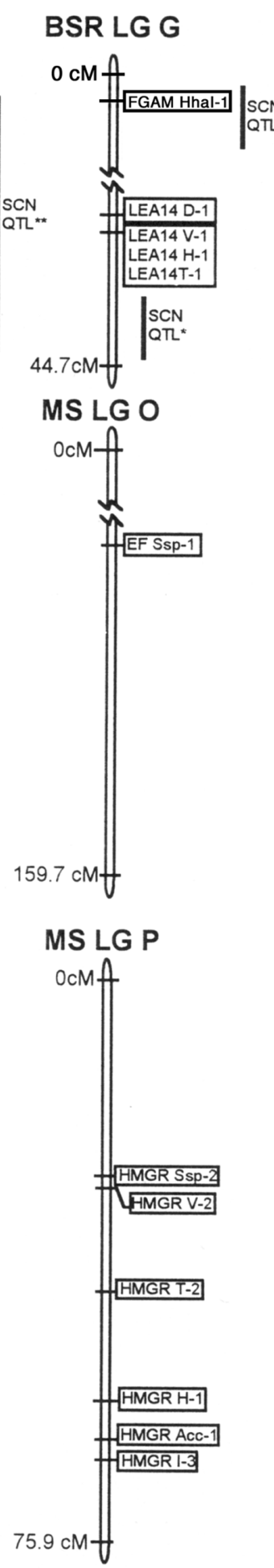

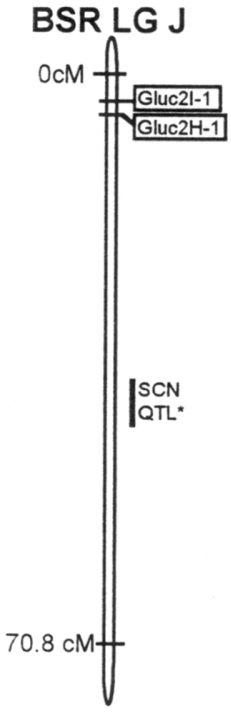

MS LG K

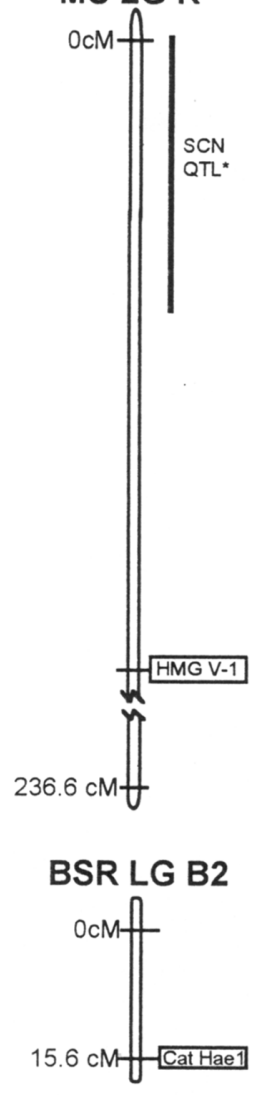

Fig. 4. Eight cDNAs on the soybean public genetic linkage map. Linkage groups beginning with MS are from the $F_{2}$ population of the A81 $356022 \times$ PI 468.916 cross (Shoemaker et al. 1996); BSR are from the recombinant inbred line population of the BSR $101 \times$ PI 437.654 cross (Baltazar and Mansur 1992). If a cDNA locus was mapped to the same linkage group in both populations, the BSR linkage group was placed to the right of the corresponding MS linkage group. cDNA locus names are shown in bold and boxed and include the restriction enzymes used in genomic DNA digestion. Cyclin $=$ accession no. D50868; EF-1a = elongation factor EF-1 $\alpha$; GLUC-2 = $\beta$-1,3-endoglucanase (U08405); HMGR = hydroxymethylglutaryl CoA reductase; HSP70 = heat shock protein HSP70 (accession no. X62799); LEA14 = late embryonic abundant protein type 14; FGAM = formylglycinamidine ribonucleotide synthetase. Quantitative trait loci (QTL) regions associated with soybean resistance to soybean cyst nematode are indicated by a vertical bar and SCN QTL. 
mapped to regions known to encode important resistance genes in soybean (Kanazin et al. 1996; Yu et al. 1996). FGAM synthetase mapped precisely to the B_053T-Bng_122D interval on linkage group $\mathrm{G}$ (Fig. 3). This position corresponds to the location encoding the major SCN resistance gene (Mudge et al. 1997) as well as the resistance locus mapped in this study. The relationship, if any, of FGAM to the resistance response is still unclear. FGAM corresponds to the purL locus in Escherichia coli (Schendel et al. 1989) and catalyzes an important step in de novo purine biosynthesis. Not surprisingly, loci associated with purine synthesis in Arabidopsis spp. have demonstrated enhanced expression in rapidly dividing cells (Senecoff et al. 1996), and derivatives of purine nucleotides are essential to a multitude of metabolic processes. The cDNA for this gene also has turned up in a collection of stress- and defense-related genes in the albostrians mutant of barley (Hess et al. 1998). Two genes involved in the purine synthesis pathway also were shown to be highly expressed in young and immature soybean nodules, which is consistent with their role in nitrogen fixation (Schnorr et al. 1996). Our data suggest that SCN resistance in PI 88287 is a recessive trait, implying that deficiency for an essential component of the plant-nematode interaction might account for the incompatible response. Consequently, we are currently investigating the possible influence of soybean FGAM synthase regulation in the root on the establishment of a compatible interaction with the cyst nematode.

If enhanced expression is indicative of a possible involvement in SCN resistance, we would predict that additional loci containing expression-enhanced genes also might be correlated with QTLs for SCN resistance response. A small interspecific mapping population in soybean was used in a recent study to uncover a previously unidentified QTL for SCN resistance. Interestingly, this QTL mapped within a several centimorgan interval that contains the LEA14 locus on linkage group G (B. Diers, personal communication). Consequently, the establishment of map locations for particular nematode-

Table 4. Reaction of VL1 on host differential lines

\begin{tabular}{lccccc}
\hline Host & \multicolumn{2}{c}{ Experiment 1 } & & \multicolumn{2}{c}{ Experiment 2 } \\
\cline { 2 - 3 } \cline { 5 - 6 } differential & Cysts/plant & Reaction $^{\mathbf{a}}$ & & Cysts/plant & Reaction $^{\mathbf{a}}$ \\
\hline Lee & 372 & SC & & 217 & SC \\
Picket & 73 & + & & 27 & + \\
Peking & 0 & - & & 0 & - \\
PI 88788 & 415 & + & & 155 & + \\
PI 90763 & 0 & - & & 0 & - \\
\hline
\end{tabular}

${ }^{a}+=$ number of females and cysts recovered was greater than or equal to $10 \%$ the number on susceptible control cultivar Lee; $-=$ number of females and cysts recovered was less than $10 \%$ the number on susceptible control cultivar Lee. $\mathrm{SC}=$ susceptible control.

Table 5. Reaction of nematode inbred VL1 on soybean lines PI 89008, PI 88287, and $F_{1}$ and $F_{2}$ plants from the PI $89008 \times$ PI 88287 cross $^{\mathrm{a}}$

\begin{tabular}{lrccc}
\hline Population & $\begin{array}{c}\text { Population } \\
\text { size }\end{array}$ & Cysts/plant & Range & $\begin{array}{c}\text { Standard } \\
\text { error }\end{array}$ \\
\hline PI 89008 & 19 & 132.0 & $90-201$ & 7.3 \\
PI 88287 & 19 & 0.5 & $0-2$ & 0.1 \\
F $_{1}$ F (resistant) & 10 & 152.0 & $69-294$ & 18.8 \\
F $_{2}$ (susceptible) & 43 & & $0-3$ & \\
\hline
\end{tabular}

${ }^{a}$ Expected ratio: 1 resistant to 3 susceptible. $\chi^{2}=1.07, P=0.7$ responsive loci in this study may assist in the future identification of additional QTLs that are important to the plant resistance response.

In this investigation, we examined the appropriateness of the PI 88287-PI 89008 strain VL1 genetic system for further in-depth investigation of SCN-soybean interaction. With regard to the infection process as well as the phenotype and genetics of susceptibility, this simplified, highly selected system appears to mirror the observations previously reported in other more complex systems. The observations made in this study should now situate us to examine the nature of gene regulation in response to nematode infection and to begin to determine the degree to which interference with this nematode-responsiveness at identified loci will influence the establishment of compatibility during the infection process.

\section{MATERIALS AND METHODS}

\section{Origin of biological materials and inoculation procedures for cytological examinations.}

The nematode inbred strain VL1 was provided by $T$. Niblack of the University of Missouri, and seeds of soybean lines PI 88287 and PI 89008 were provided by R. Nelson of the University of Illinois. Plants were grown in growth chambers at $25^{\circ} \mathrm{C}$ under fluorescent light illumination with a 14-h day-10-h night schedule. Seven-day-old seedlings (four per planting) were transferred to $500 \mathrm{~cm}^{3}$ of a sterilized soil and sand mixture (1:1) and inoculated with 10 cracked cysts of nematode strain VL1. An infection cycle was completed approximately 4 to 5 weeks after inoculation (Table 1 ). The infection site was localized by identifying sites on the root's surface where the infecting female protrudes. For mRNA and protein preparations and for fixation and resin embedding of infected root material, roots were inspected under the stereo microscope and the protruding female was carefully removed from the infection site. The infection sites then were carefully dissected from the root and either frozen in liquid nitrogen or submerged into fixative. Although this was an effective means of delimiting infection sites, it limited us to the dissection of middle-to-late stages of syncytium development. Sections of uninfected roots of the same age were harvested in parallel for use as controls.

\section{Specimen preparation for cytology.}

Plant tissues were cut into small blocks of about $1 \mathrm{~mm}$ and immediately fixed in phosphate buffer, $\mathrm{pH} 7.3$, containing 1 mM 3-maleidobenzoic acid $N$-hydroxysuccinimide ester, $0.5 \%$ Triton X-100, and $50 \mathrm{mM}$ ethylene glycol-bis( $\beta$-aminoethyl ether)- $N, N, N^{\prime}, N^{\prime}$-tetraacetic acid for $1 \mathrm{~h}$, followed by fixation in phosphate buffer containing 3\% glutaraldehyde. After dehydration in an ethanol series, embedding was performed in LR White or Quetol resins (Electron Microscopy Sciences, Fort Washington, PA, U.S.A.), according to the manufacturer's instructions. Thick sections $(1 \mu \mathrm{m})$ were cut with a glass knife on an Ultracut-E microtome (Reichert-Jung, Vienna, Austria). The sections were mounted on glass slides, dried on a hot plate, and stained with $0.5 \%$ methylene blue and azure II in $0.5 \%$ sodium borate. The sections were then cover slipped and viewed under a Microphot-FX light microscope system (Nikon, Tokyo, Japan). 


\section{Soybean clone generation and selection.}

Infected and uninfected lateral root tissues were collected from inoculated and noninoculated seedlings, respectively. For infected roots, tissue was sampled from roots at 6 to 14 days after inoculation and pooled for mRNA preparation (Sambrook et al. 1989). Below is a brief summary of the procedures for cDNA subtraction and differential display with tissues from infected versus uninfected susceptible line PI 89008 .

\section{Differential display}

and subtractive hybridization protocol.

The protocol for differential display analysis was adapted from that of Liang et al. (1995) and Liang and Pardee (1992). Total RNA was extracted from uninfected and VL1-infected roots, as outlined in Gelvin et al. (1994). Differential display protocol bands of interest were excised and eluted from the gel. These cDNAs were reamplified with the same primer combinations (primers contained restriction endonuclease designation $[E c o R I]$ sites) used in the differential display, which allowed for cloning into the pGEM-3Zf vector (Promega, Madison, WI, U.S.A.).

The cDNA subtraction protocol followed procedures described in Ausubel et al. (1988), with specifications according to Wilson et al. (1994). Briefly, RNA prepared from VL1infected (tracer) and uninfected (driver) tissues was reverse transcribed to cDNA and ligated to EcoRI adapters. After subtraction procedures, the enriched cDNAs were ligated into the EcoRI site of the pGEM-3Zf vector.

Plasmids from the clones retrieved through the abovementioned procedures were isolated, and the inserts were retrieved for hybridization to soybean genomic DNA by digestion with EcoR1, according to standard procedures (Sambrook et al. 1989). Clones were subjected to sequence analysis by the fluorescent labeled primer cycle sequencing kit with 7deaza-dGTP (Amersham International, Little Chalfont, Buckinghamshire, U.K.) in an ALFexpress automated sequencer (Pharmacia Biotech, Uppsala, Sweden). Clone identities were determined by blasting sequences against the databases at GenBank and SWISS-PROT. Vector sequence contamination was detected with VecScreen.

\section{Total RNA-mRNA preparation and quantification for RT-PCR.}

To isolate RNA from infected tissues, areas of PI 89008 roots with heavy SCN infestations were chosen. Total RNA was extracted from these roots by the RNeasy Plant Mini Kit (Qiagen, Chatsworth, CA, U.S.A.) and subjected to DNase treatment with RNase-free DNase (Stratagene, La Jolla , CA, U.S.A.). The resulting RNA was subjected to RNA-PCR with specific gene primers to ensure the absence of DNA template and quantitated in a spectrophotometer (Beckman Instruments, Fullerton, CA, U.S.A.). For the RT-PCR assay, $100 \mathrm{ng}$ of RNA prepared from uninfected and infected tissues was taken in RNase-free microtubes and dried in a vacuum concentrator (Labconco, Kansas City, MO, U.S.A.). Afterward, the RNA was resuspended in equal volumes of RNase-free water to achieve equal concentrations of RNA per microliter. These RNA templates were used for RT-PCR, as described below.

For mRNA isolation, total leaf RNA was isolated by the RNeasy Plant Mini Kit, followed by mRNA purification with the PolyATtract System 1000 (Promega). Root mRNA was isolated directly from uninfected and infected tissues $(5 \mathrm{mg}$ of starting material) of soybean-susceptible line PI 89008 with the PolyATtract System 1000. Direct isolation of mRNA from root tissue was carried out in order to minimize the loss of template. Spectrophotometric quantification was not possible with root mRNA samples as a result of the minute quantities of mRNA that were isolated. Hence, quantification was carried out by a comparative dilution series (25- to 25,000-fold) with unknown starting amounts of root mRNA and known amounts of leaf mRNA that was subjected to RT-PCR. Specific primers for soybean 18S rRNA (see Table 1) were used for PCR, taking advantage of rRNA as a regular contaminant in mRNA samples purified with Oligo(dT) to measure mRNA concentrations. This approach was adopted from the Relative RT-PCR protocol by Ambion (Austin, TX, U.S.A.). After RTPCR (for conditions, see below), the entire reaction was run on a $1.2 \%$ agarose gel, stained with ethidium bromide, photographed, and the image saved digitally (Gel Print 2000i, BioPhotonics Corp., Dexter, MI, U.S.A.). The image was analyzed by the GPTools computer program (BioPhotonics), which quantifies the pixel intensities of each band. According to quantification results, mRNA volumes were adjusted in the RT reaction until equal intensity of the bands produced by PCR for the samples being compared was achieved. This titration allowed us to subject nearly equal amounts of template to the first-strand cDNA reaction. This approach is similar in its experimental basis to Ambion's Relative RT-PCR protocol, wherein the $18 \mathrm{~S}$ rRNA signal is attenuated by adjusting the ratio of nonextendible $18 \mathrm{~S}$ primers to normal $18 \mathrm{~S}$ rRNA primers to achieve equal signal intensities. We utilized a dilution approach that applies the same principle in allowing us to achieve equal amplification of the control 18S rRNA sequences from the samples under consideration.

\section{Oligonucleotide primer design for RT-PCR.}

Primers were designed to produce amplification products of 250 to $450 \mathrm{bp}$ by RT-PCR on the basis of sequence information. We considered an overall $\mathrm{G}+\mathrm{C}$ content of 60 to $65 \%$, ending with a mandatory $\mathrm{G}$ or $\mathrm{C}$ on both ends. The calculated $T_{\mathrm{m}}$ (at $50 \mathrm{mM}$ salt concentration and $50 \mathrm{nM}$ primer concentration) was approximately $62^{\circ} \mathrm{C}$ (Breslauer et al. 1986). For genes selected on the basis of reports of enhanced expression in other plant-pathogen interactions (Cramer et al. 1993; Laxalt et al. 1996; Niebel et al. 1995; Niebel et al. 1996; Van der Eycken et al. 1996; Wang et al. 1995; Yoshikawa et al. 1990), sequence information was retrieved from the database and corresponding primers were designed. Primers discriminating among members of the same gene family were designed according to the most divergent gene sections, chosen on the basis of a prior multiple amino acid sequence alignment by the CLUSTAL program (Higgins and Sharp 1988). For cytosolic HMG CoA reductase, no soybean sequence data were available. Therefore, conservative regions of homologous plant genes were first identified by the CLUSTAL program (Higgins and Sharp 1988). Degenerate primers were designed for PCR displaying the structure $5^{\prime}>$ GCHAARGCHGTKGGWAARGT < $3^{\prime}$ and $5^{\prime}>$ TAWCCCCAYTCRTTRTCRTACCA $<3^{\prime}$ for NAPDH, and $5^{\prime}>\mathrm{CCWGCHGCH}-$ GTKAAYTGGAT < $3^{\prime}$ and $5^{\prime}>$ GCWCCYTTMACWCC $<3^{\prime}$ for $\mathrm{HMG} \mathrm{CoA}$ reductase. Upon sequence verification of the 
cloned genomic DNA, nondegenerate, matching primers were synthesized for use in RT-PCR experiments.

\section{Reverse transcription of total RNA-mRNA and RT-PCR.}

For first-strand cDNA synthesis, the following components were included in a $25-\mu \mathrm{l}$ reaction: $400 \mu \mathrm{M}$ of each deoxynucleoside triphosphate (dNTP), RT buffer $(50 \mathrm{mM}$ Tris- $\mathrm{HCl}$, $\mathrm{pH} 8.3 ; 50 \mathrm{mM} \mathrm{KCl} ; 10 \mathrm{mM} \mathrm{MgCl}{ }_{2} ; 0.5 \mathrm{mM}$ spermidine; and $10 \mathrm{mM}$ dithiothreitol), $40 \mu \mathrm{M}$ random primer (Boehringer Mannheim, Indianapolis, IN, U.S.A.), template RNA or mRNA, and DEPC-treated water. Last, we added 2.5 units of AMV reverse transcriptase (Promega; Boehringer Mannheim) to the reaction, and the mixture was incubated at $55^{\circ} \mathrm{C}$ for 30 min in a thermal cycler with a heated lid (MJ Research, Watertown, MA, U.S.A.). This first-strand cDNA template was used in a normal PCR.

A $25-\mu \mathrm{l}$ PCR master mix contained the following components: $125 \mu \mathrm{M}$ dNTP, Taq DNA polymerase reaction buffer $(50 \mathrm{mM} \mathrm{KCl} ; 10 \mathrm{mM}$ Tris-HCl, $\mathrm{pH} 9.0$; and $0.1 \%$ Triton $\mathrm{X}-$ 100), $100 \mathrm{nM}$ specific primers (for primer design, see above), 2.5 units of Taq DNA polymerase, and $2.5 \mu$ l of first-strand cDNA template from the above reaction. Reactions were performed in thin-walled tubes in a PTC100 programmable thermal cycler (MJ Research). The PCR cycling profile was $94^{\circ} \mathrm{C}$ for $2 \mathrm{~min}$ for initial denaturation followed by 35 (RNA template) to 40 (mRNA template) cycles of $94^{\circ} \mathrm{C}$ for $30 \mathrm{~s}, 55^{\circ} \mathrm{C}$ for $30 \mathrm{~s}, 72^{\circ} \mathrm{C}$ for $1 \mathrm{~min}$, and ending with an extension at $72^{\circ} \mathrm{C}$ for $7 \mathrm{~min}$. The entire reaction was subjected to electrophoresis in $1.2 \%$ agarose, stained with ethidium bromide, and photographed. The positive control 18S rRNA template reaction was run each time with all primer sets. Each assay was run with negative controls (water in place of mRNA), and the obtained product size was evaluated to match the expected size according to available nucleotide sequence data. A single RT reaction was used to generate a template for the PCR required to test candidate genes together with control sequences for a single experiment, a process that eliminated the variation inherent in multiple RT reactions. All PCR amplification results were confirmed a minimum of four times from templates obtained independently. The possibility of amplification from genomic DNA contamination was ruled out by treatment of RNA-mRNA templates with DNase (RNase-free). As an added precaution, primers were designed for particular genes (EF-1 $\alpha$ and HMGR) to span intron sequences and allow amplification of different-sized products from cDNA versus genomic DNA templates (data not shown).

For preparation of gene-mapping probes, the RT-PCR products were eluted from the gel with GenElute columns (Supelco, Bellefonte, PA, U.S.A.), reamplified with the same pair of primers used in its initial amplification, and run in a preparative agarose gel. The amplified fragment was retrieved from the gel in the same way, further purified with the Wizard DNA Purification Kit (Promega), and quantified spectrophotometrically.

\section{Plant populations for genetic analysis.}

Reciprocal crosses were made between PI 89008 and PI 88287. Each cross was harvested individually, and crosses that produced two- and three-seeded pods were analyzed genetically. One seed from each of 10 pods was grown in $18-\mathrm{cm}$ pots containing organic soil mix to produce the $\mathrm{F}_{2}$ generation.
The plants were grown in the greenhouse, and DNA samples from each $F_{1}$ plant were evaluated by restriction fragment length polymorphism analysis to ensure that they were hybrids. A second seed from these pods was used in nematode screening experiments.

\section{Bulked segregant analysis.}

Bulked segregant analysis (Michelmore et al. 1991), in combination with RAPD PCR analysis, was used to analyze the $F_{2}$ population. Resistant (zero to three cysts per root) and susceptible (48 cysts per root) bulks each contained an equal concentration of DNA from 16 plants. Random primers were used to screen the bulks for polymorphisms.

\section{Gene mapping.}

Two soybean populations were used to map the selected cDNAs. The first was a population of $57 \mathrm{~F}_{2}$ individuals derived from the cross of a Glycine max parent, A81 356022, and a G. soja parent, PI 468.916 (Shoemaker et al. 1996). The second, a population of $100 \mathrm{RIL}$ in the $\mathrm{F}_{6: 7}$ generation, was derived from a BSR $101 \times$ PI 437.654 cross (Baltazar and Mansur 1992). PI 437.654 is resistant to all known races of SCN in the United States (Meyers and Anand 1991). Resistance to SCN in this population was mapped to linkage groups A (near the I locus), G, and M (Webb et al. 1995).

Radioactively labeled RT-PCR products were used as probes against parental DNA blots of the two populations. Parental DNA of both populations was digested with DraI, EcoRI, EcoRV, HaeIII, HindIII, and TaqI. Additionally, parental DNAs from the $\mathrm{F}_{2}$ population were digested with AccI, AluI, BamHI, BclI, HhaI, HnfI, RsaI, and SspI. Once polymorphisms were detected, the radioactively labeled probes were hybridized against the population DNAs. In the RIL population, DNA was extracted from at least 30 seedlings per line. The DNA extraction, blotting, hybridization, and autoradiography methods used followed Keim et al. (1990).

The computer program MapMaker 3.0 (Lander et al. 1987) was used to map cDNAs in the two populations. The defaults of a LOD score of 3.0, a Haldane estimation (Haldane 1919), and a maximum recombination of $30 \%$ were used. Linkage groups were identified according to the U.S. Department of Agriculture-Agricultural Research Service public map (Shoemaker et al. 1996) and gene orders were assigned. The "compare," "try," and "ripple" commands were used to include a locus on a preexisting linkage group.

\section{Nematode pathotype testing.}

To characterize the pattern of VL1 infection, a replicated standard race test was performed (Golden et al. 1970). For each test, three plants of differential host lines Lee, Picket, Peking, PI 88788, and PI 90763 were inoculated. SCN differential host lines were provided by the University of Illinois germ plasm bank and J. Wilcox of Purdue University.

\section{Assay for soybean reaction to VL1 inoculation in segregating populations.}

Nematode cysts were collected from the root and soil by the procedure described by Faghihi et al. (1986). Collected and rinsed cysts were crushed with a rubber stopper and passed through a 100-mesh $(150 \mu \mathrm{M})$ sieve nested in a 400 -mesh $(38 \mu \mathrm{M})$ sieve. Intact cysts were collected on the 100-mesh 
sieve and the crushing was repeated. The inoculum was diluted to 4,500 eggs per milliliter.

Seven $F_{1}$ plants (the second seed from two- or three-seeded pods) and $165 \mathrm{~F}_{2}$ seeds were screened with VL1. Seeds were germinated in sand, and roots of 7-day-old seedlings were inoculated with 4,500 VL1 eggs per plant. Plants were grown in $7 \times 10-\mathrm{cm}$ pots containing a 3:1 sand-soil mixture. Pots were maintained in a growth chamber with a 14-h photoperiod and were fertilized weekly with Masterblend 20:10:20 (Chicago, IL, U.S.A). After 28 days, cysts were collected, as previously described, and counted under a dissecting microscope.

\section{ACKNOWLEDGMENTS}

The authors acknowledge C.-N. Liu for his contributions to the characterization of the infection process over time as well as to the cDNA subtraction and differential display procedures for cloning of plant genes induced upon infection. We also gratefully acknowledge M. Alley, J. Jensen, and Z. Yan for technical assistance and P. Lockard and D. Van Horn of Purdue University Veterinary Medical School EM Facility (J. Turek, director) for their skilled assistance with cytological work. We also thank D. Sherman (Department of Botany and Plant Pathology) for her valuable advice and M. M. Paz, Department of Agronomy, Iowa State University, for independent mapping confirmation. This work was supported by grants to S. Mackenzie from the Indiana Soybean Board and the USDA-NRI.

\section{LITERATURE CITED}

Acedo, J. R., Dropkin, V. H., and Luedders, V. D. 1984. Nematode population attrition and histopathology of Heterodera glycinessoybean associations. J. Nematol. 16:48-57.

Ausubel, F. M., Brent, R., Kingston, R. E., Moore, D. D., Seidman, J. G., Smith, J. A., and Struhl, K. 1988. Current Protocols in Molecular Biology. Wiley Interscience, New York.

Baltazar, M. B., and Mansur, L. 1992. Identification of restriction fragment length polymorphisms (RFLPs) to map soybean cyst nematode resistance genes in soybean. Soybean Genet. Newsl. 19:120-122.

Bird, D. M. 1996. Manipulation of host gene expression by root knot nematodes. J. Parasitol. 82:881-888.

Bird, D. M., and Riddle, D. L. 1994. A genetic nomenclature for parasitic nematodes. J. Nematol. 26:138-143.

Bird, D. M., and Wilson, M. A. 1994. DNA sequence and expression analysis of root-knot nematode-elicited giant cell transcripts. Mol. Plant-Microbe Interact. 7:419-424.

Breslauer, K. J., Frank, R., Blocker, H., and Marky, L. A. 1986. Predicting DNA duplex stability from the base sequence. Proc. Natl. Acad. Sci. USA 11:3746-3750.

Chang, S. J. C., Doubler, T. W., Kilo, V. Y., Abu-Thredeih, J., Prabhu, R., Freire, V., Suttner, R., Klein, J., Schmidt, M. E., Gibson, P. T., and Lightfoot, D. A. 1997. Association of loci underlying resistance to soybean sudden death syndrome (SDS) and cyst nematode (SCN) Race 3. Crop Sci. 37:965-971.

Concibido, V. C., Denny, R. L., Boutin, S. R., Hautea, R., Orf, J. H., and Young, N. D. 1994. DNA marker analysis of loci underlying resistance to soybean cyst nematode (Heterodera glycines Ichinohe). Crop Sci. 34:240-246.

Concibido, V. C., Denny, R. L., Lange, D. A., Orf, J. H., and Young, N. D. 1996a. RFLP mapping and marker-assisted selection of soybean cyst nematode resistance in PI 209332. Crop Sci. 36:1643-1650.

Concibido, V. C., Young, N. D., Lange, D. A., Denny, R., Danesh, D. and Orf, J. H. 1996b. Targeted comparative genome analysis and qualitative mapping of a major partial resistance gene to the soybean cyst nematode. Theor. Appl. Genet. 93:234-241.

Concibido, V. C., Lange, D. A., Denny, R. L., Orf, J. H,. and Young, N. D. 1997. Genome mapping of soybean cyst nematode resistance genes in "Peking," PI 90763, and PI 88788 using DNA markers. Crop Sci. 37:258-264.

Cramer, C. L., Weissenborn, D., Cottingham, C. K., Denbow, C. J.,
Eisenback, J. D., Radin, D. N, and Yu, X. 1993. Regulation of defense-related gene expression during plant-pathogen interactions. J. Nematol. 25:507-518.

Cregan, P. B., Jarvik, T., Bush, A. L., Shoemaker, R. C., Lark, K. G., Kahler, A. L., Kaya, N., Van Toai, T. T., Lohnes, D. G., Chung, J., and Specht, J. E. 1999. An integrated genetic linkage map of the soybena genome. Crop Sci. 39:1464-1490.

Endo, B. 1991. Ultrastructure of initial responses of susceptible and resistant soybean roots to infection by Heterodera glycines. Rev. Nematol. 14:73-94.

Endo, B. 1992. Cellular responses to infection. Pages 37-49 in: Biology and Management of the Soybean Cyst Nematode, R. D. Riggs and J. A. Wrather, eds. American Phytopathological Society, St. Paul, MN, U.S.A.

Faghihi, J., Ferris, J. M., and Ferris, V. R. 1986. Heterodera glycines in Indiana: I. Reproduction of geographical isolates on soybean differentials. J. Nematol 18:169-172.

Gelvin, S. B., and Schilperoort, R. A. 1994. Plant Molecular Biology Manual. 2nd ed. Kluwer Academic Publishers, Dordrecht, The Netherlands.

Golden, A. M., Epps, J. M., Riggs, R. D., Ducllos, L. A, Fox, J. A., and Bernard, R. L. 1970. Terminology and identity of intraspecific forms of the soybean-cyst nematode. Plant Dis. Rep. 54:544-546.

Gunning, B. E. S, and Steer, M. W. 1996. Plant Cell Biology. Structure and Function. Jones and Bartlett Publishers International, London.

Haldane, J. B. S. 1919. The combination of linkage values, and the calculation of distances between the loci of linked factors. J. Genet. 8:299-309

Hermsmeier, D., Mazarei, M., and Baum, T. J. 1998. Differential display analysis of the early compatible interaction between soybean and the soybean cyst nematode. Mol. Plant-Microbe Interact. 11:1258-1263.

Hess, R. W., Golz, R., and Börner, T. 1998. Analysis of randomly selected cDNAs reveals the expression of stress- and defence-related genes in the barley mutant albostrians. Plant Sci. 133:191-201.

Higgins, D. G., and Sharp, P. M. 1988. CLUSTAL: A package for performing multiple sequence alignment on a microcomputer. Gene 73:237-244.

Kanazin, V., Marek, L. F., and Shoemaker, R. C. 1996. Resistance gene analogs are clustered and conserved in soybean. Proc. Natl. Acad. Sci. USA 93:11746-11750.

Keim, P., Diers, B., Olson, T., and Shoemaker, R. 1990. RFLP mapping in soybeans: Association between marker loci and variation in quantitative traits. Genetics 126:735-742.

Kim, K. S., and Riggs, R. D. 1992. Cytoplasmic reactions of resistant soybean plants to nematode invasion. Pages 157-168 in: Biology and Management of the Soybean Cyst Nematode. R. D. Riggs and J. A. Wrather, eds. American Phytopathological Society, St. Paul, MN, U.S.A.

Lander, E., Green, P., Abrahamson, J., Barlow, A., Daley, M., Lincoln, S., and Newburg, L. 1987. MAPMAKER: An interactive computer package for constructing primary genetic linkage maps of experimental and natural populations. Genomics 1:174-181.

Lauritis, J. A., Rebois, R. V., and Graney, L. S. 1983 Development of Heterodera glycines Ichinohe on soybean, Glycine max (L.) Merr., under gnotobiotic conditions. J. Nematol. 15:272-281

Laxalt, A. M., Cassia, R. O., Sanllorenti, P. M., Madrid, E. A., Andreu, A. B., Daleo, G. R., Conde, R. D., and Lamattina, L. 1996. Accumulation of cytosolic glyceraldehyde-3-phosphate dehydrogenase RNA under biological stress conditions and elicitor treatments in potato. Plant Mol. Biol. 30:961-972.

Liang, P., and Pardee, A. B. 1992. Differential display of eukaryotic messenger RNA by means of the polymerase chain reaction. Science 257:967-971.

Liang, P., Bauer, D., Averboukh, L., Warthoe, P., Rohrwild, M., Muller, H., Strauss, M., and Pardee, A. B. 1995. Analysis of altered gene expression by differential display. Methods Enzymol. 254:304-321.

Luedders, V. D. 1987. A recessive gene for a zero cyst phenotype in soybean. Crop Sci. 27:604-606.

Mahalingam, R., and Skorupska, H. T. 1996. Cytological expression of early response to infection by Heterodera glycines Ichinohe in resistant PI 437654. Genome 39:986-998.

Meyers, G. O., and Anand, S. C. 1991. Inheritance of resistance and genetic relationships among soybean plant introductions to races of soybean cyst nematode. Euphytica 55:197-201. 
Michelmore, R. W., Paran, I., and Kesseli, R. V. 1991. Identification of markers linked to disease-resistance genes by bulked segregant analysis: A rapid method to detect markers in specific genomic regions by using segregating populations. Proc. Natl. Acad. Sci. USA 88:9828-9832.

Mudge, J., Cregan, P. B., Kenworthy, J. P., Kenworthy, W. J., Orf, J. H., and Young, N. D. 1997. Two microsatellite markers that flank the major soybean cyst nematode resistance locus. Crop Sci. 37:16111615 .

Niebel, A., Heungens, K., Barthels, N., Inzé, D., Van Montagu, M., and Gheysen, G. 1995. Characterization of a pathogen-induced potato catalase and its systemic expression upon nematode and bacterial infection. Mol. Plant-Microbe Interact. 8:371-378.

Niebel, A., de Almeida Engler, J., Hemerly, A., Ferreira, P., Inze, D., Van Montagu, M, and Gheysen, G. 1996. Induction of cdc2a and cyc1At expression in Arabidopsis thaliana during early phases of nematode-induced feeding cell formation. Plant J. 10:1037-1043.

Opperman, C. H., Taylor, C. G., and Conkling, M. A. 1994. Root-knot nematode-directed expression of a plant root-specific gene. Science 263:221-223.

Rao Arelli, A. P., Wrather, J. A., and Anand, S. C. 1992. Soybean resistance to soybean cyst nematode Race 3 is conditioned by an additional dominant gene. Crop Sci. 32:862-864.

Sambrook, J., Fritsch, E. F., and Maniatis, T. 1989 Molecular Cloning: A Laboratory Manual, 2nd ed. Cold Spring Harbor Laboratory, Cold Spring Harbor, NY, U.S.A.

Schendel, F. J., Mueller, E., Stubbe, J., Shiau, A., and Smith, J. M. 1989. Formylglycineamide ribonucleotide synthetase from Escherichia coli: Cloning, sequencing, overproduction, isolation, and characterization. Biochemistry 28:2459-2471.

Schnorr, K. M., Laloue, M., and Hirel, B. 1996. Isolation of cDNAs encoding two purine biosynthetic enzymes of soybean and expression of the corresponding transcripts in roots and root nodules. Plant Mol. Biol. 32:751-757.

Senecoff, J. F., McKinney, E. C., and Meagher, R. B. 1996. De novo purine synthesis in Arabidopsis thaliana. II. The PUR7 gene encoding 5'-phosphoribosyl-4-(N-succinocarboxamide)-5-aminoimidaxole synthetase is expressed in rapidly dividing tissues. Plant Physiol.
112:905-917.

Shoemaker, R. C., Polzin, K. M., Lorenzen, L. L., and Specht, J. E. 1996. Molecular genetic mapping in soybean. Pages 37-56 in: Biotechnology in Agriculture. No. 14. Soybean: Genetics, Molecular Biology and Biotechnology. D. P. S. Verma and R. C. Shoemaker, eds. CAB International, Wallingford, Oxon, UK.

Sijmons, P. C. 1993. Plant-nematode interactions. Plant Mol. Biol. 23:917-931.

Van der Eycken, W., de Almeida Engler, J., Inze, D., Montagu, M., and Gheysen, G. 1996. A molecular study of root-knot nematode-induced feeding sites. Plant J. 9:45-54.

Vierling, R. A., Faghihi, J., Ferris, V. R., and Ferris, J. M. 1996. Association of RFLP markers with loci conferring broad-based resistance to the soybean cyst nematode (Heterodera glycines). Theor. Appl Genet. 92:83-86.

Wang, M., Heimovaara-Dijkstra, S., Meulen, R. M., Knox, J. P., and Neill, S. J. 1995. The monoclonal antibody JIM19 modulates abscissic acid action in barley aleurone protoplasts. Planta 196:271-278.

Webb, D. M., Baltazar, B. M., Rao Arelli, A. P., Schupp, J., Clayton, K., Keim, P., and Beavis, W. D. 1995. Genetic mapping of soybean cyst nematode Race 3 resistance loci in the soybean PI 437654. Theor. Appl. Genet. 91:574-581.

Wilson, M. A., Bird, D. M., and Van der Knaap, E. 1994. A comprehensive subtractive cDNA cloning approach to identify nematodeinduced transcripts in tomato. Phytopathology 84:299-303.

Yamamoto, Y. T., Cheng, C. L., and Conkling, M. A. 1990. Rootspecific genes from tobacco and Arabidopsis homologous to an evolutionary conserved gene family of membrane channel proteins. $\mathrm{Nu}$ cleic Acids Res. 18:7449.

Yoshikawa, M., Takeuchi, Y., and Horino, O. 1990. A mechanism for ethylene-induced disease resistance in soybean: Enhanced synthesis of an elicitor-releasing factor, beta-1,3-endoglucanase. Physiol. Mol. Plant Pathol. 37:367-376.

Yu, Y. G., Buss, G. R., and Maroof, M. A. S. 1996. Isolation of a superfamily of candidate disease-resistance genes in soybean based on a conserved nucleotide-binding site. Proc. Natl. Acad. Sci. USA 93:11751-11756 